\title{
Phytochemical and antioxidant properties of Diodia sarmentosa swartz leaves
}

\author{
Okoroafor Henry Chinedu*, Awagu Fidelis Emenike, Azeke Ehijie Augusta \\ Perishable Crops Research Department, Nigerian Stored Products Research Institute, \\ Mile 4, Rumueme, Port Harcourt, Rivers State, 500262, Nigeria \\ *Corresponding author: okoroaforchinedu@gmail.com; ORCID ID:0000-0001-7333-179X
}

Received: 26 November 2020; revised: 30 December 2020; accepted: 31 December 2020

\begin{abstract}
This research studied proximate, phytochemical and antioxidant properties of Diodia sarmentosa leaves. The ethanol and aqueous extracts of the leaves significantly inhibited 2,2-diphenyl-1-picrylhydrazyl $\left(\mathrm{DPPH}^{\circ}\right)$ radical formation with $\mathrm{IC}_{50}$ values of 10.994 and $10.121 \mu \mathrm{g} / \mathrm{mL}$ respectively, compared to the ascorbic acid standard $\left(\right.$ IC $_{50}$ value $\left.=17.916 \mu \mathrm{g} / \mathrm{mL}\right)$. The aqueous extract exhibited more inhibitory effect on thiobarbituric acid-reactive species (TBARS) with IC ${ }_{50}$ values of $2.657 \mu \mathrm{g} / \mathrm{mL}$ while the ethanol extract had an $\mathrm{IC}_{50}$ value of $8.53 \mu \mathrm{g} / \mathrm{mL}$ compared to butylated hydroxytoluene standard $\left(\mathrm{IC}_{50}=2.142 \mu \mathrm{g} / \mathrm{mL}\right)$. For the total antioxidant capacity assay, the aqueous extract had higher ascorbic acid equivalent values than the ethanol extract. However, the two solvent extracts showed antioxidant activity. Diodia sarmentosa leaves possess useful phytochemicals which are indicative of its antioxidant properties.
\end{abstract}

Keywords: Antioxidant; Diodia sarmentosa; phytochemical; proximate

\section{INTRODUCTION}

The use of plants for culinary and ethno medicinal purposes can be dated back to ancient history, even as far back as the "stone age" era. Plant leaves have been the most exploited for these purposes especially due to the proximate and phytochemical contents of these leaves. The proximate composition of these leaves reveal their nutritional status and make them suitable in food processing. The ethno medicinal uses of these leaves can be attributed to the phytochemical composition of the leaves which are also indicative of their antioxidant activities. Hence, a study on these vital components reveals the usefulness of a plant's leaves. Diodia sarmentosa Sw commonly known as "Tropical buttomweed" [1], is a perennial herb without a true root system. It has a hairy leaf and stem which are about $7 \mathrm{~cm}$ and $4 \mathrm{~m}$ long respectively. It grows in bushy vegetation, riverine areas and on rocky grounds. It is majorly inhabited in tropical Africa, Asia, America and the Mascarene Islands. It is a dicot which belongs to the family Rubiaceae and the genus Diodia.

In some parts of Nigeria, especially the south western region, the leaves are crushed and used in preparing stew or soup and it is locally known as "Ewe Opaeyin" or "Ewe Ohaigbo". D. sarmentosa leaves are used in treating injuries, oedema [2] and haemorrhoids (pile).
The whole plant is taken with pepper and salt for the treatment of dysentery in south western Nigeria [3, 4]. The antiulcer potential of Diodia sarmentosa (whole plant) [5] and its anti-inflammatory and analgesic activities [2] have been demonstrated. The anti-diabetic properties of $D$. sarmentosa has also been revealed [6]. This was determined using the $n$-hexane leaf extract of $D$. sarmentosa. Other species belonging to the genus Diodia has also gained wide applications. Studies on Diodia scandens revealed their use as poultry feed for ruminant animals [7]. There are also postulations that the plant has pharmacological properties, hence, could be used in the treatment of rheumatoid, oedema, inflammations [7] and brain thromboplastin [8]. $D$. scandens is also used traditionally in some parts of Eastern Nigeria to treat snake bites [8]. The plant also serves as a laxative and oxytocic agent in the treatment of uterine inertia and postpartum haemorrhage [9]. According to the same finding, the aqueous extracts are used to enhance micturition and sexual performance by rural inhabitants of Ikwere and Etche local government areas of Rivers State, Nigeria [9]. The anti-fungal properties of $D$. scandens have also been studied [10]. Presently, there is no data showing a comprehensive proximate composition, phytochemical and antioxidant properties of $D$. sarmentosa leaves.

(C) The Author(s). 2020 Open access. This article is distributed under the terms of the Creative Commons Attribution 4.0 International License (http://creativecommons.org/licenses/by/4.0/), which permits unrestricted use, distribution, and reproduction in any medium, provided you give appropriate credit to the original author(s) and the source, provide a link to the Creative Commons license, and indicate if changes were made. 


\section{EXPERIMENTAL}

Plant collection and identification: Fresh samples of $D$. sarmentosa leaves were collected from farmlands and from natural vegetation within Federal University of Technology, Owerri (FUTO) premises. It was identified by Prof. Iloegbulam I.I. of the Department of Crop Science. A picture of a portion of $D$. sarmentosa plant is displayed in Figure 1.

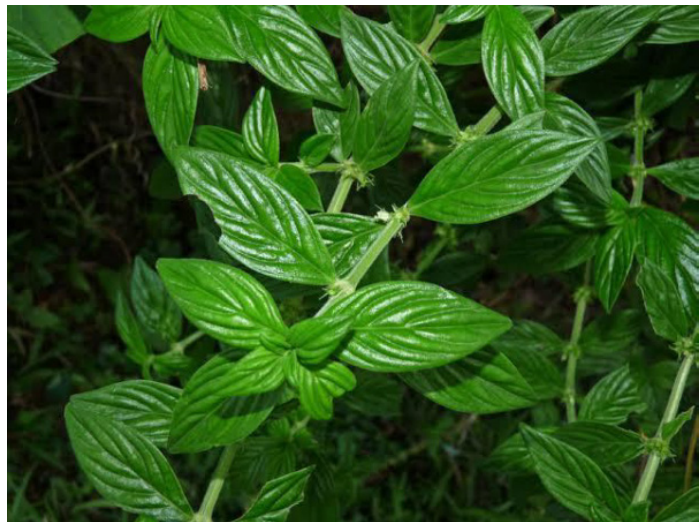

Fig. 1. An aerial part of $D$. sarmentosa plant

Preparation of plant extract and extraction: Fresh leaves of $D$. sarmentosa were rinsed using distilled $\mathrm{H}_{2} \mathrm{O}$, dried at room temperature and then in a laboratory oven at $40{ }^{\circ} \mathrm{C}$. The dried plant material was grinded into fine powder and $160 \mathrm{~g}$ was weighed, soaked in ethanol (800 $\mathrm{mL}$ ) for $48 \mathrm{~h}$ and placed on an orbital shaker. Filtration was done using Whatman No.1 filter paper placed inside a funnel, then dried at $40{ }^{\circ} \mathrm{C}$ using a rotary evaporator.

Proximate analysis of sample: Determination of moisture content was carried out using a laboratory oven at $105^{\circ} \mathrm{C}$. Ash was determined using an electric furnace at $550{ }^{\circ} \mathrm{C}$. Soxhlet apparatus was used in the determination of the crude fat. Crude protein was determined using Kjeldahl method. Percentage carbohydrate was done by difference. These were all done using AOAC method [11].

Qualitative phytochemical screening: The test sample $(0.2 \mathrm{~g})$ was placed in separate test tubes to assay for phytochemicals as follows:

Saponin: Frothing test was used in the detection of saponin, which was confirmed by constant foaming.

Flavonoid: Ammonium test method was used in the determination of flavonoid. A yellowish colouration confirmed the presence of flavonoid.

Carbohydrate: Molisch's method was used in the determination of carbohydrate. This was confirmed by the formation of a brown ring.

Phenol: Ferric chloride test was used in the determination of phenol. A greenish colouration was observed and this confirmed the presence of phenol.

Reducing Sugar: Reducing sugar was confirmed by a reddish colouration using Fehling's method.

Glycoside: Fehling's method was used in glycoside determination. Glycoside was confirmed by a reddish colouration.
Tannins: Ferric Chloride Method was used to determine the presence of tannins. A blue colouration was observed which confirmed the presence of tannins.

Alkaloid: Presence of alkaloid was determined using Wagner and Dragendorff's reagent. No precipitate was formed.

Steroids: To determine the presence of steroids, Lieberman-Buchard test was used. Steroids were detected by a greenish colouration.

Terpenoid: A violet colouration after dissolution in ethanol and treatment with acetic anhydride and conc. $\mathrm{H}_{2} \mathrm{SO}_{4}$ revealed the presence of terpenoids.

\section{Quantitative phytochemical screening:}

Determination of phenolics: Total phenolics was determined using Follin-Ciocalteau reagent method. Gallic acid was used as standard. Folin-Ciocalteu reagent was used in oxidizing $D$. sarmentosa leaves extract. This was then neutralized using $\mathrm{Na}_{2} \mathrm{CO}_{3}$. A portion $(100 \mu \mathrm{L})$ of the different concentrations $(15.63$, $31.25,62.5 \mu \mathrm{g} / \mathrm{mL}$ ) of this extract was put into a mixture of $0.5 \mathrm{~mL}$ Folin-Ciocalteau reagent ( 0.1 dilution) and $1.5 \mathrm{~mL}$ sodium carbonate $2 \%(\mathrm{w} / \mathrm{v})$, then incubated for about $15 \mathrm{~min}$ at $25^{\circ} \mathrm{C}$. The absorbance of the blue coloured solution was read at $765 \mathrm{~nm}$ and results expressed in $\mathrm{mg}$ of gallic acid equivalent (GAE)/100 g of dry weight of plant powder.

Determination of tannins: The leaves extract $(1 \mathrm{~mL})$ of $D$. sarmentosa was put into a solution containing $0.5 \mathrm{~mL}$ Folin-Ciocalteau reagent, $1 \mathrm{~mL}$ sodium carbonate and $8 \mathrm{~mL}$ of distilled water. This was kept at $25^{\circ} \mathrm{C}$ for about $30 \mathrm{~min}$. It was then centrifuged to get a supernatant and absorbance read at $765 \mathrm{~nm}$. The results were expressed as $\mathrm{mg}$ tannic acid/100 $\mathrm{g}$ of dry weight of plant powder.

Determination of flavonoid: Zhishen colorimetric method was used in the determination of flavonoid [12]. The diluted sample solution $(0.5 \mathrm{~mL})$ was put into a mixture containing $2 \mathrm{~mL}$ of distilled $\mathrm{H}_{2} \mathrm{O}$ and $0.15 \mathrm{~mL}$ of sodium nitrate (5\%) solution. After a short while, $0.15 \mathrm{~mL}$ of $10 \% \mathrm{AlCl}_{3}$ (aq) was put into the solution and kept for about 6 min. Diluted sodium hydroxide (4\%) solution $(2 \mathrm{~mL})$ was added to bring the total volume to $5 \mathrm{~mL}$. The absorbance was taken after $15 \mathrm{~min}$ at 510 $\mathrm{nm}$ against water blank. The results were expressed as $\mathrm{mg} / 100 \mathrm{~g}$ of dry weight of plant powder.

Determination of terpenoids: A portion of $D$. sarmentosa leaves $(1 \mathrm{~g})$ was extracted using ethanol $(50 \mathrm{~mL})$. The filtrate $(2.5 \mathrm{~mL})$ was mixed with $5 \%$ aqueous phosphomolybdic acid $(2.5 \mathrm{~mL})$ and 2.5 $\mathrm{mL}$ concentrated tetraoxosulphate $(\mathrm{VI})$. After that, the volume of the solution was made up to $12.5 \mathrm{~mL}$ after 30 min using ethanol. The absorbance was read at 700 $\mathrm{nm}$. The results were expressed as $\mathrm{mg} / 100 \mathrm{~g}$ of dry weight of plant powder.

Determination of steroids: A portion of $D$. sarmentosa leaves $(1 \mathrm{~g})$ was extracted with $20 \mathrm{~mL}$ of ethanol. The filtrate $(2 \mathrm{~mL})$ was mixed with $2 \mathrm{~mL}$ of chromogen solution and kept at room temperature $\left(25^{\circ} \mathrm{C}\right)$ for about $30 \mathrm{~min}$. 
Then the absorbance was read at $550 \mathrm{~nm}$. The results were expressed as $\mathrm{mg} / 100 \mathrm{~g}$ of dry weight of plant powder. Determination of saponin: Extraction of the sample (1 g) was done using $10 \mathrm{~mL}$ petroleum ether. After that, an additional $10 \mathrm{~mL}$ of petroleum ether was mixed with the solution and then subjected to dryness by evaporation. The residue obtained after dryness was dissolved in 6 $\mathrm{mL}$ of ethanol. Then, $2 \mathrm{~mL}$ of the solution was mixed with $2 \mathrm{~mL}$ of chromogen and left at room temperature for about $30 \mathrm{~min}$. Absorbance of the solution was read at $550 \mathrm{~nm}$. The results were expressed as $\mathrm{mg} / 100 \mathrm{~g}$ of dry weight of plant powder.

Determination of glycosides: A sample of $D$. sarmentosa leaves $(1 \mathrm{~g})$ was extracted with $50 \mathrm{~mL}$ of distilled water. Alkaline picrate $(4 \mathrm{~mL})$ solution was mixed with 1 $\mathrm{mL}$ of the sample filtrate and heated for about $5 \mathrm{~min}$. Absorbance was read at a wavelength of $490 \mathrm{~nm}$. The results were expressed as $\mathrm{mg} / 100 \mathrm{~g}$ of dry weight of plant powder.

Reducing sugar: Extraction of the sample $(1 \mathrm{~g})$ was carried out using $20 \mathrm{~mL}$ of distilled water. Alkaline copper reagent $(1 \mathrm{~mL})$ was mixed with the filtrate $(1 \mathrm{~mL})$ and heated for about $5 \mathrm{~min}$. Then $1 \mathrm{~mL}$ of phosphomolybdic acid reagent and $2 \mathrm{~mL}$ of distilled water was mixed with the resultant solution and absorbance read at $420 \mathrm{~nm}$. The results were expressed as $\mathrm{mg} / 100 \mathrm{~g}$ of dry weight of plant powder.

Determination of soluble carbohydrates: Extraction of the sample $(1 \mathrm{~g})$ was done using $50 \mathrm{~mL}$ of distilled water. The filtrate $(\mathrm{l} \mathrm{mL})$ was mixed with picric acid solution and the absorbance read at $580 \mathrm{~nm}$. The results were expressed as $\mathrm{mg} / 100 \mathrm{~g}$ of dry weight of plant powder.

In vitro screening for antioxidant activities:

Quantitative $D P P H^{\circ}$ radical scavenging assay: Quantitative $\mathrm{DPPH}^{\circ}$ was determined according to a modified Gyamfi method [13]. The test was performed in triplicates. The sample extracts (1 $\mathrm{mL}$ each) were diluted 2-fold in $10 \mathrm{~mL}$ of water mixed with $0.5 \mathrm{~mL}$ of $0.076 \mathrm{mM} \mathrm{DPPH}^{\circ}$. After that, it was mixed properly and kept away from sunlight at $25^{\circ} \mathrm{C}$ for about $25 \mathrm{~min}$. An aqueous solution $\left(1 \mathrm{ml}\right.$ ) of $0.076 \mathrm{mM} \mathrm{DPPH}^{\circ}$ was used as a negative control while the positive control was L-Ascorbic acid. Absorbance was read at $517 \mathrm{~nm}$.

Thiobarbituric acid-reactive species (TBARS): Thiobarbituric acid-reactive species assay was carried out by a modified method of Banerjee [14]. This aimed at quantifying the amount of lipid peroxide formed. Egg yolk homogenate served as lipid-rich media [15]. The sample $(100 \mu \mathrm{L})$ was mixed with egg homogenate (500 $\mu \mathrm{L}$ ) in a test tube and distilled water was used to make up the volume to $1.0 \mathrm{~mL}$. A mixture of $0.075 \mathrm{M} \mathrm{FeSO}_{4}(50$ $\mu \mathrm{l})$ and $0.1 \mathrm{M} \mathrm{L}$-Ascorbic acid $(20 \mu \mathrm{L})$ were added to the solution, and kept at $37{ }^{\circ} \mathrm{C}$ for about an hour. Then 0.2 $\mathrm{mL}$ EDTA $(0.1 \mathrm{M})$ and $1.5 \mathrm{~mL}$ of TBA reagent were put into each sample and heated for $15 \mathrm{~min}$ at $100{ }^{\circ} \mathrm{C}$. After cooling, the samples were centrifuged for $10 \mathrm{~min}$ at 3000 rpm. The absorbance was read at $532 \mathrm{~nm}$. Butylated hydroxytoluene $(\mathrm{BHT})$ was used as the assay standard.
Total antioxidant capacity (TAC) assay: Phosphomolybdate method was used in assaying for total antioxidant capacity. A $0.1 \mathrm{~mL}$ aliquot of different concentrations (15.63, 31.25, 62.5, 125, 250, 500, 1000 $\mu \mathrm{g} / \mathrm{mL}$ ) of the extract and ascorbic acid (1000, 500, $250,125,62.5,31.25,15.63 \mu \mathrm{g} / \mathrm{mL}$ ) was mixed with 1 $\mathrm{mL}$ of reagent solution $\left(0.6 \mathrm{M} \mathrm{H}_{2} \mathrm{SO}_{4}, 0.028 \mathrm{M} \mathrm{Na}_{2} \mathrm{HPO}_{4}\right.$ and $\left.0.004 \mathrm{M}\left(\mathrm{NH}_{4}\right)_{2} \mathrm{MoO}_{4}\right)$. The test tubes were heated in a water bath at $95{ }^{\circ} \mathrm{C}$ for $90 \mathrm{~min}$. After cooling, the absorbance was read at $765 \mathrm{~nm}$. The reagent solution $(1 \mathrm{~mL})$ was used as blank and ascorbic acid was used as standard.

Statistical analysis: Pearson's correlation coefficient at $95 \%$ confidence interval was used in the determination of correlation coefficient between analytes. One way analysis of variance (ANOVA) was used in determining the standard deviation between means of values.

\section{RESULTS AND DISCUSSION}

Proximate analysis: The proximate analysis of $D$. sarmentosa leaves evaluated the moisture, ash, crude fat, crude fibre, crude protein and carbohydrate content. The percentage of carbohydrate was found to be $(59.07 \%)$; moisture content $(10.66 \%)$; crude protein $(8.57 \%)$; crude fibre $(7.8 \%)$; ash content $(7.50$ $\%)$ and crude fat $(6.40 \%)$.

Qualitative phytochemical analysis: D. sarmentosa leaves extract revealed the presence of saponin, flavonoid, and carbohydrate, phenol, reducing sugar, glycoside, tannin, steroid and terpenoid. However, alkaloid was absent (Table 1).

Table 1. Qualitative phytochemical analysis of D. sarmentosa leaves extract

\begin{tabular}{|c|c|c|}
\hline Phytochemical & Observation & Bioavailability \\
\hline Saponin & Persistent foaming & ++ \\
\hline Flavonoid & A yellowish colouration & ++ \\
\hline Carbohydrate & $\begin{array}{l}\text { Brown ring formation at } \\
\text { the interface }\end{array}$ & ++ \\
\hline Phenol & A greenish colouration & +++ \\
\hline Reducing sugar & A brick red precipitate & +++ \\
\hline Glycoside & A brick red colouration & +++ \\
\hline Tannin & A blue black colouration & +++ \\
\hline Steroid & $\begin{array}{l}\text { Colour change from violet } \\
\text { to green }\end{array}$ & +++ \\
\hline Terpenoid & $\begin{array}{l}\text { Colour change from pink } \\
\text { to violet }\end{array}$ & +++ \\
\hline Alkaloid & No ppt formed & ND \\
\hline
\end{tabular}

Notice: + Slightly available; ++ Moderately available; +++ Very much available; ND Not detected

Quantitative phytochemical analysis: Quantitative phytochemical screening of the phytochemicals revealed a very high quantity of carbohydrate (3223 $\pm 3.95 \mathrm{mg} / 100 \mathrm{~g})$ and reducing sugar $(2410.87 \pm 6.15$ $\mathrm{mg} / 100 \mathrm{~g}$ ) in $D$. sarmentosa leaf extracts. 
This suggest that the leaf extracts have high energy content and may be edible. High quantities of phenol $(1121.02 \pm 5.67 \mathrm{mg}$ GAE/100 g), a potent antiinflammatory phytochemical, was also observed. Relatively high quantities of flavonoid (320.15 \pm 1.83 $\mathrm{mg} / 100 \mathrm{~g})$ and terpenoids $(149.41 \pm 3.64 \mathrm{mg} / 100 \mathrm{~g})$, potent anti-inflammators were observed. The results of the quantitative phytochemical constituents of $D$. sarmentosa leaves extract are shown in Table 2 .

Table 2. Quantitative phytochemical analysis of D. sarmentosa leaves

\begin{tabular}{ll}
\hline Phytochemical & Mean \pm std $(\mathbf{m g} / \mathbf{1 0 0} \mathbf{~ g})$ \\
\hline Total phenolics & $1121.02 \pm 5.67$ \\
\hline Total tannins & $64.68 \pm 1.08$ \\
\hline Total flavonoid content & $320.15 \pm 1.83$ \\
\hline Terpenoids & $149.41 \pm 3.64$ \\
\hline Steroids & $20.84 \pm 0.13$ \\
\hline Saponins & $5.07 \pm 0.86$ \\
\hline Glycosides & $50.38 \pm 0.16$ \\
\hline Reducing sugar & $2410.87 \pm 6.15$ \\
\hline Soluble carbohydrates & $3223 \pm 3.95$ \\
\hline
\end{tabular}

In vitro antioxidant activities of leaves extracts of D. sarmentosa: $D P P H^{\circ}$ assay: A graph of inhibition (\%) was plotted against $\mathrm{DPPH}^{\circ}$ concentration $(\mu \mathrm{g} / \mathrm{mL})$ (Fig. 2). There was a significant $(r=-0.955, p<0.05)$ negative Pearson correlation between $\mathrm{DPPH}^{\circ}$ aqueous and concentration while a significant $(r=0.704, p<0.05)$ positive correlation was observed between $\mathrm{DPPH}^{\circ}$ ethanol and concentration. $\mathrm{DPPH}^{\circ}$ aqueous was negatively $(r=-0.511, p<0.05)$ correlated with the standard (ascorbic acid) while $\mathrm{DPPH}^{\circ}$ ethanol was positively $(r=0.257$, $p<0.05)$ correlated with the standard.

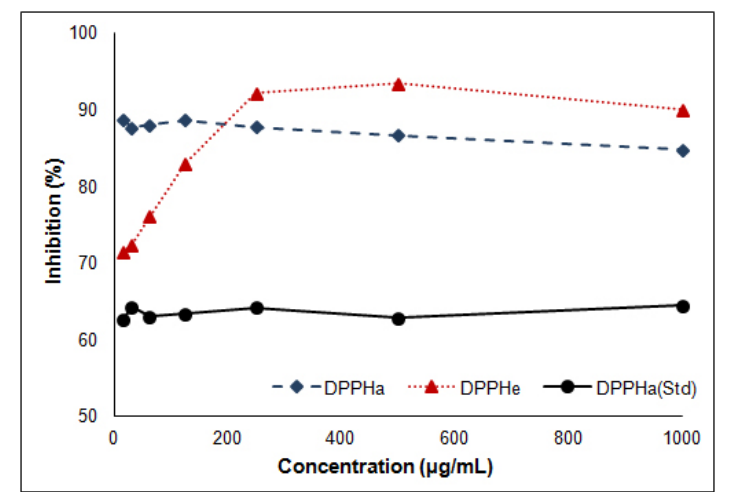

Fig. 2. Percentage $\mathrm{DPPH}^{\circ}$ inhibition of aqueous and ethanol extracts of $D$. sarmentosa leaves.

DPPHa - DPPH of aqueous extract; DPPHe - DPPH of ethanol extract; DPPH Std - DPPH of ascorbic acid standard

TBARS assay: A graph of inhibition (\%) was plotted against concentration $(\mu \mathrm{g} / \mathrm{mL})$ (Fig. 3). There was significant $(r=0.553, p<0.05)$ positive Pearson correlation between TBARS aqueous and concentration and significant $(r=-0.834, p<0.05)$ negative Pearson correlation between TBARS ethanol and concentration. There was also significant $(r=0.824, p<0.05)$ positive Pearson correlation between TBARS aqueous and BHT standard while there was significant $(r=-0.526$, $p<0.05$ ) negative Pearson correlation between TBARS ethanol and BHT standard.

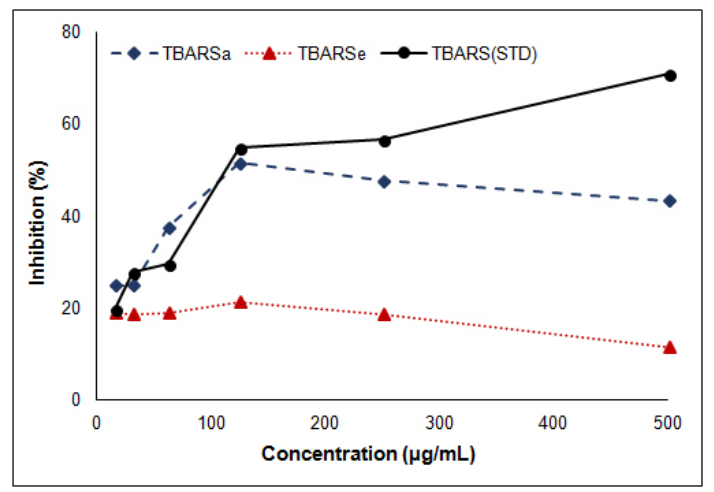

Fig. 3. Percentage TBARS inhibition of aqueous and ethanol extracts of $D$. sarmentosa leaves.

TBARSa - TBARS for aqueous extract; TBARSe - TBARS for ethanol extract; TBARS (Std) - TBARS for BHT standard

Total antioxidant capacity: A graph of ascorbic acid equivalent was plotted against concentration (Fig. 4). There was significant $(r=0.987, p<0.05)$ positive Pearson correlation between total antioxidant capacity of aqueous extract and concentration. There was also significant $(r=0.424, p<0.05)$ positive Pearson correlation between total antioxidant capacity of ethanol extract and concentration.

D. sarmentosa leaves contain protein (8.57\%), carbohydrate $(59.07 \%)$, fat $(6.4 \%)$, fibre $(7.8 \%)$, ash $(7.50 \%)$ and moisture $(10.66 \%)$.

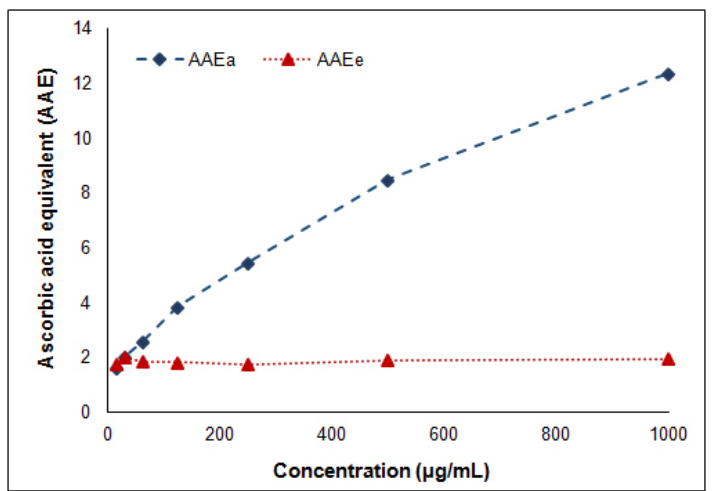

Fig. 4. Total antioxidant capacity of aqueous and ethanol extracts of $D$. sarmentosa leaves.

AAEa - Ascorbic acid equivalent of aqueous extract; AAEe- Ascorbic acid equivalent of ethanol extract.

This reveals the nutritional composition of the leaves and suggest that it could be used as part of a healthy meal.

Qualitative phytochemical screening of 
$D$. sarmentosa leaves revealed the presence of saponin, flavonoid, terpenoid, phenol, reducing sugar, glycoside, tannin, steroid and carbohydrate except alkaloid which was absent (Table 1). Presence of saponin indicates that the leaves can be useful in treating yeast and fungal infections [16]. This agrees with the findings of Umoh [2] who reported the ability of $D$. sarmentosa leaves in preventing inflammation.

Flavonoids are natural antioxidants [17] which boost immune function, protect against microbial infections and prevent the formation of free radicals [18]. Phenols prevent inflammation and also boost the body immune system [19, 20]. This supports the findings of Umoh [2], who reported the anti-inflammatory properties of the leaves. Presence of glycosides suggest that the leaves extract have the ability to lower blood pressure [21]. Presence of tannins suggest that the leaves can be used in the treatment of wounds [22]. Results of this study validates that of Akah [5] regarding presence of tannins and of the antiulcer effect of $D$. sarmentosa leaves.

$\mathrm{DPPH}^{\circ}$ assay of the leaves extract of $D$. sarmentosa revealed significant antioxidant activity (Fig. 2). The $I C_{50}$ (inhibitory concentration at $50 \%$ ) value of aqueous and ethanol extracts of $D$. sarmentosa (10.121 and $10.994 \mu \mathrm{g} / \mathrm{mL}$ respectively) were significantly lower than the $\mathrm{IC}_{50}$ value of ascorbic acid $(17.916 \mu \mathrm{g} / \mathrm{mL})$. Lower values reveal better antioxidant activity [23, 24]. In the Thiobarbituric acid assay (TBARS) (Fig. 3), the aqueous extract showed a significantly higher percentage inhibition compared to the ethanol extract. The $\mathrm{IC}_{50}$ values for the aqueous and ethanol extracts were 2.657 and $8.53 \mu \mathrm{g} / \mathrm{mL}$ respectively compared to $\mathrm{IC}_{50}$ value of $\mathrm{BHT}$ standard, which was $2.142 \mu \mathrm{g} /$ $\mathrm{mL}$. This suggest that water soluble phytochemicals possess a stronger potential to reduce malondialdehyde (MDA) formation. For the total antioxidant capacity assay (Fig. 4), the aqueous extract had higher ascorbic acid equivalent values compared to the ethanol extract. This is quite normal since the solubility of ascorbic acid increase with increasing polarity [25]. However, the two solvent extracts showed antioxidant activity.

\section{CONCLUSIONS}

The results of proximate assessment of $D$. sarmentosa leaves which revealed the edibility of the leaves, supports the use of the leaves in southern Nigeria for culinary purposes. Evidence from the qualitative and quantitative phytochemical evaluation as well as the different in vitro antioxidant assessments of $D$. sarmentosa leaves suggest that the plant has useful phytochemicals, indicative of its antioxidant properties.

\section{REFERENCES}

1. Ekpo Z., Ambi A.A., Magaji M.G., Ojeje S.O. (2019) Pharmacognostic and anti-inflammatory studies on the aerial parts of Diodia sarmentosa Swartz (Rubiaceae). Journal of Pharmaceutical
Development and Industrial Pharmacy, 1(3), 1-15.

2. Umoh U.F., Ajibesin K.K., Ubak N.G. (2016) Preliminary anti-inflammatory and analgesic effects of Diodia sarmentosa Sw. leaf in rodents. World Journal of Pharmacy and Pharmaceutical Sciences, 5(12), 203-212.

3. Hemans M., Akoeginou A., Vander M.J. (2004) Medicinal plants used to treat malaria in Southern Benin. Economic Botany, 58, S239-52.

4. Soladoye M.O., Osipitan A.A., Sonibara M.A., Chukwuma E.C. (2010) From vagabond to ethno botanical relevance: weeds of the campus sites of Olabisi Onabanjo University, Awo-Iwoye, Nigeria. Ethno botanical leaflets. 4, 546-58. https://opensiuc.lib.siu.edu/ebl/vol2010/iss4/17

5. Akah P.A., Orisakwe O.E., Gamaniel K.S., Shittu A. (1998) Evaluation of Nigerian traditional medicines: II. Effects of some Nigerian folk remedies on peptic ulcer. J. Ethnopharmacol., 62(2), 123-7. https://doi.org/10.1016/s0378-8741(98)00060-9

6. Elechi N.A., Okezie-Okoye C., Abo K.A. (2020) Anti-diabetic potentials of Diodia sarmentosa Sw (Rubiaceae) leaves of aloxan-induced diabetic rats. Saudi Journal of Medical and Pharmaceutical Sciences, 6(9), 622-626. https://doi.org/10.36348/sjmps.2020.v06i09.006

7. Essiet U.A., Bala D.N., Agbakahi J.A. (2010) Pharmacognostic studies of the leaves and stem of Diodia scandens SW in Nigeria. Archives of Applied Science Research, 2(5), 184-198. http://scholarsresearchlibrary.com/archive.html

8. Onuaguluchi G., Okeke P.C. (1989) Preliminary in vitro studies on the antagonistic effects of an ethanolic extract from Diodia scandens on Echis carinatus venom-induced changes in the clothing of human blood. Phytother. Res., 3, 11-14.

9. Onuaguluchi G., Nwafor P. (1999) Pharmacological basis for the use of the antivenene water soluble extract of Diodia scandens as a Laxative, Oxytocic agent and a Possible Aphrodisiac in Traditional Medicine Practice in Eastern Nigeria. Phytother. Res., 13, 459-463.

10. Ogu G.P., Madagwu E.C., Eboh O.J., Ezeadila J.O. (2011) Antifungal evaluation of Diodia scandens SW leaf extract against some dermatophytes in Ukwuani Region of Delta State, Nigeria, Int. Res. J. Pla. Sci., 2(10), 311-316.

11. AOAC (1990) Official Methods of Analysis. 15th Edn. AOAC, Washington, DC, USA, 200-210

12. Zhishen J., Mengcheng T., Jianming W. (1999) The determination of flavonoid contents in mulberry and their scavenging effects on superoxide radicals. Food Chemistry, 64, 555-559. https://doi.org/10.1016/S0308-8146(98)00102-2

13. Gyamfi M.A., Yonamine M., Aniya Y. (1999) Free radical scavenging action of medicinal herbs from Ghana: Thonningia Sanguine on experimentallyinduced liverinjuries. Gen. Pharmacol., 32, 661-667. 
https://doi.org/10.1016/s0306-3623(98)00238-9

14. Banerjee A., Dasgupa N., De B. (2005) In vitro study of antioxidant activity of Syzygium cumini fruit. Food Chemistry, 90(4), 727-733. https://doi.org/10.1016/j.foodchem.2004.04.033

15. Ruberto G., Baratta M.T., Deans S.G., Dorman H.J.D. (2000) Antioxidant and antimicrobial activity of Foeniculum vulgare and Crithmum maritimum essential oils. Planta. Med., 66, 687-693.

https://doi.org/10.1055/s-2000-9773

16. Sheikh N., Kumar Y., Misra A.K., Pfoze L. (2013) Phytochemical screening to validate the ethnobotanical importance of root tubers of Dioscorea species of Meghalaya, North East India. Journal of Medicinal Plants Studies, 1(6), 62-69.

17. Kim S.Y., Kim J.H., Kim S.K., Oh M.J., Jung M.Y. (1994) Antioxidant activities of selected oriental herb extracts. Journal of the American Oil Chemists' Society, 71(6), 633-640. https://doi.org/10.1007/BF02540592

18. Barakat M.Z., Shahab S.K., Darwin N., Zahemy E.I. (1993) Determination of ascorbic acid from plants. Analytical Biochemistry, 53, 225-245.

19. Okwu D.E., Omodamino O.D. (2005) Effects of hexane extract and phytochemical content of Xylopia aethiopica and Ocimum gratissimum on uterus of guinea pig. Bio. Research., 3(2), 40-44. https://doi.org/10.4314/br.v3i2.28589

20. Okwu D. E. (2004) Phytochemicals and vitamin contents of indigenous species of South Eastern
Nigeria, Journal of Sustainable Agriculture and Environment, 6, 30-37.

21. Nyarko A.A., Addy M.E. (1990) Effects of aqueous extract of Adenia cissampeloides on blood pressure and serum analyte of hypertensive patients. Phytotherapy Res., 4(1), 25-28. https://doi.org/10.1002/ptr.2650040107

22. Ajuru M.G., Williams L.F., Ajuru G. (2017) Qualitative and quantitative phytochemical screening of some slants used in ethnomedicine in the Niger Delta Region of Nigeria. Journal of Food and Nutrition Sciences, 5(5), 198-205. https://doi.org/10.11648/j.jfns.20170505.16

23. Rezaeizadeh A., Zuki A.B.Z., Abdollahi M., Goh Y.M., Noordin M.M., et al. (2011) Determination of antioxidant activity in methanolic and chloroformic extracts of Momordica charantia. African Journal of Biotechnology, 10(24), 4932-4940. https://doi.org/10.5897/AJB10.1972

24. Bhupendra K.K., Mahesh G.T., Yogendra S. (2012) Free radical scavenging effect of various extracts of leaves of Balanites aegyptiaca (L.) Delile by DPPH method. Asian Journal of Plant Science and Research, 2(3), 323-329.

25. Neto A.C.R., Pires R.F., Malagoni R.A., Franco, M.R. (2010) Solubity of vitamin C in water, ethanol, propan-1-ol, water + ethanol, and water + propan-1-ol at (298.15 and 308.15) K. J. Chem. Eng., 55(4), 1718-1721. https://doi.org/10.1021/je900687y 